\title{
Assessment of genetic variability in common whitefish from the catchment area of the Oder river using microsatellite markers
}

\author{
MAGDALENA ACHREM, ${ }^{1}$ LIDIA SKUZA, ${ }^{2}$ LUCYNA KIRCZUK, ${ }^{3}$ \\ JÓZEF DOMAGAŁA, ${ }^{4}$ MAŁGORZATA PileCKA-RAPACZ, ${ }^{5}$ ROBERT CZERNiAWSKI ${ }^{6}$
}

${ }^{1}$ University of Szczecin, Faculty of Biology, Department of Cell Biology, Molecular Biology and Biotechnology Center, Wąska 13, 71-415 Szczecin, Poland, e-mail: magdalena.achrem@usz.edu.pl

${ }^{2}$ University of Szczecin, Faculty of Biology, Department of Cell Biology, Molecular Biology and Biotechnology Center, Wąska 13, 71-415 Szczecin, Poland, e-mail: 1idia.skuza@usz.edu.pl

${ }^{3}$ University of Szczecin, Faculty of Biology, Department of General Zoology, Felczaka 3c, 71-412 Szczecin, Poland, e-mail: lucyna. kirczuk@usz.edu.pl

${ }^{4}$ University of Szczecin, Faculty of Biology, Department of General Zoology, Felczaka 3c, 71-412 Szczecin, Poland, e-mail: jozef. domagala@usz.edu.pl

${ }^{5}$ University of Szczecin, Faculty of Biology, Department of General Zoology, Felczaka 3c, 71-412 Szczecin, Poland, e-mail: małgorzata. pilecka-rapacz@usz.edu.pl

${ }^{6}$ University of Szczecin, Faculty of Biology, Department of General Zoology, Felczaka 3c, 71-412 Szczecin, Poland, e-mail: robert. czerniawski@usz.edu.pl

Keywords Coregonus maraena, SSR, genetic variability

Abstract Common whitefish (Coregonus maraena) in Poland belongs to the endangered species. The degradation of the environment causes common whitefish to lose its natural reproduction sites. The natural genetic structure of whitefish has been compromised by anthropogenetic activities involving eutrophication, river regulation, the introduction of non-native species and as well as excessive exploitation of the species. The genetic variability of common whitefish (Coregonus maraena) from 2 sites: Pomeranian Bay and the lower Oder river, was assessed using microsatellite markers. A total of 45 caught individuals were analysed (26 from Pomeranian Bay and 19 from the Oder river). Polymorphism at nine loci, Str60INRA, Str73INRA, Strutta 12, OmyFgt1TUF, Str85INRA, Str591INRA, Ssa85, Ssa197, T3-13 was assessed. The results indicated that all the investigated populations showed a high level of genetic variability. The level of genetic variability was determined using the $F_{S T}$ parameter and was high investigated populations $(0.215)$. Microsatellite analysis demonstrated a higher observed heterozygosity as compared with the expected heterozygosity in all the investigated populations. The $F_{I S}$ coefficient values below zero in all the investigated populations of common whitefish indicate the excess of heterozygotes. The high number of heterozygotes may be related with a more intense influx of genes from outside of the local population. The study demonstrated that microsatellite markers (SSR) are very useful in the assessment of the genetic variability of common whitefish (Coregonus maraena). Our results characterize the selected populations of whitefish and may be useful for further research on this endangered species. 


\section{Ocena zmienności genetycznej siei ze zlewni Odry z wykorzystaniem markerów mikrosatelitarnych}

Słowa kluczowe Coregonus maraena, SSR, zmienność genetyczna

Streszczenie Sieja (Coregonus maraena) w Polsce zaliczana jest do gatunków zagrożonych. Degradacja ich naturalnego środowiska spowodowała, że gatunek ten traci miejsca naturalnego rozrodu. Naturalna struktura genetyczna siei została naruszona przez działania antropogeniczne z udziałem eutrofizacji, regulacji rzek, wprowadzaniem gatunków obcych, jak również nadmierną eksploatację tego gatunku. Zmienność genetyczną dwóch populacji siei (Coregonus maraena) z Zatoki Pomorskiej i Dolnej Odry oceniano za pomocą markerów mikrosatelitarnych. W sumie analizowano 45 pozyskanych osobników (26 z Zatoki Pomorskiej i 19 z Dolnej Odry). W pracy oceniano polimorfizm dziewięciu loci: Str60INRA, Str73INRA, Strutta 12 OmyFgt1TUF, Str85INRA, Str591INRA, Ssa85, Ssa197, T3-13. Wyniki wskazują, że obie badane populacje wykazywały wysoką zmienność genetyczną. Stopień zmienności genetycznej ustalono za pomocą parametru $F_{S T}$ i była ona wysoka dla badanych populacji-wynosiła 0,215 . Analiza sekwencji mikrosatelitarnych wykazała wyższą obserwowaną heterozygotyczność w porównaniu z heterozygotycznością oczekiwaną wszystkich badanych populacji. Wartości współczynników $F_{I S}$ poniżej zera we wszystkich badanych populacjach siei ukazuje nadmiar heterozygot. Wysoka liczba heterozygot może być związana z bardziej intensywnym napływem genów spoza lokalnej populacji. Niniejsze badania ukazały, że markery mikrosatelitarne (SSR) markerów są bardzo przydatne w ocenie zmienności genetycznej siei (Coregonus maraena). Nasze wyniki ukazały charakterystykę dwóch wybranych populacji siei i mogą być przydatne do dalszych badań dotyczących tego zagrożonego gatunku.

\section{Introduction}

Common whitefish (Coregonus maraena) in Poland belongs to the endangered species (Witkowski et al., 2009). Natural populations of this species in Poland occur in Pomeranian Bay and Lake Łebsko (Heese, 1999). Moreover, common whitefish inhabits reservoirs and coastal waters of the Baltic Sea, as well as lakes, e.g., Lake Miedwie and Lake Wigry (Szczerbowski, 2000). The species inhabits clean, cool and well-aerated water. The degradation of the environment causes common whitefish to lose its natural reproduction sites. In the recent years, the number of Polish lakes inhabited by common whitefish has decreased significantly, which is caused by the deterioration of spawning sites (Wilkonska, Zuromska, 1982), as well as excessive exploitation of the species (Witkowski et al., 2009). Currently, large-scale species restoration programmes are being carried out in many lakes. Mass introduction of the fish has been conducted without any preliminary identification of individuals (Szczerbowski, 2000). Introducing closely related individuals derived from a small number of spawners may lead to the impoverishment of the gene pool (Fraser, 2008). However, the restoration of endangered species should be accompanied by genetic monitoring (Foop-Bayat, Wiśniewska, 2010). Such studies are conducted in common whitefish inhabiting Lake Łebsko (Wiśniewska et al., 2010). Common whitefish observed in the Oder mouth constitutes a large stable population used as a source for introductions. Therefore, it is vital to perform genetic analysis of the species, which will permit a more effective fisheries management. The aim of this study was to assess the genetic variability of common whitefish (Coregonus maraena) from 2 sites, i.e. Pomeranian Bay and the lower Oder river, using microsatellite markers. 


\section{Material and methods}

\section{Research subject}

The analysis was performed in common whitefish from 2 sites: Pomeranian Bay and the lower Oder river (Figure 1), in which the fish putatively form a local population. A total of 45 caught individuals were analysed (26 from Pomeranian Bay and 19 from the Oder river). The fish were weighed and measured, and samples of muscle tissue were taken. The samples were subsequently frozen at $-70^{\circ} \mathrm{C}$.

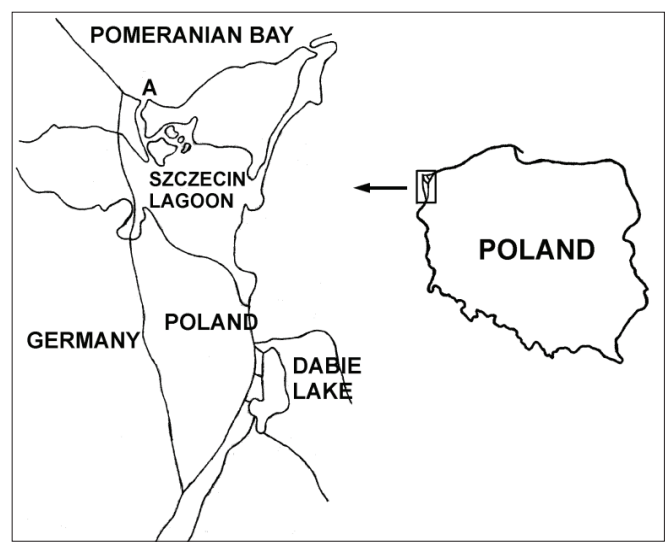

Figure 1. Map of the Poland selected sampling location. Research area: Pomeranian Bay and Oder River (A)

\section{Isolation of genomic DNA}

DNA was extracted from $0.2 \mathrm{~g}$ muscle tissue taken from every caught individual of the investigated fish population. The material was placed in $1.5 \mathrm{ml}$ tubes and $1 \mathrm{ml}$ extraction buffer (100 mM Tris- $\mathrm{HCl}, 200 \mathrm{mM} \mathrm{NaCl}, 0.2 \%$ SDS, $5 \mathrm{mM}$ EDTA and $100 \mu \mathrm{g} / \mathrm{ml}$ proteinase $\mathrm{K}$ ) was added. The mixture was incubated at $55^{\circ} \mathrm{C}$ for $12 \mathrm{~h}$ and then centrifuged at $6000 \times \mathrm{g}$ for $15 \mathrm{~min}$. The supernatant was transferred into a new tube and $700 \mu \mathrm{l}$ isopropanol was added. The mixtures were centrifuged again at $6000 \times \mathrm{g}$ for $15 \mathrm{~min}$. The supernatant was discarded and the remaining pellet was resuspended in $400 \mu 170 \% \mathrm{EtOH}$. The mixtures were centrifuged again at $6000 \times \mathrm{g}$ for $5 \mathrm{~min}$, the alcohol was discarded and the samples were dried. The pellet was dissolved in $20 \mu \mathrm{TE}$ buffer. The extracts were stored at $-20^{\circ} \mathrm{C}$. The quantity and the purity of DNA was determined using the BioRad SmartSpec ${ }^{\mathrm{TM}}$ Plus spectrophotometer.

\section{PCR-SSR analysis}

Nine microsatellite sequences were analysed (Table 1): Str60INRA, Str73INRA (Estoup et al., 1993), Strutta 12 (Poteaux et al., 1995), OmyFgt1TUF (Slettan, 1995), Str85INRA, Str591INRA (Presa et al., 1996), Ssa85, Ssa197 (O’Reilly et al., 1996), T3-13 (Estoup et al., 1998). The reactions were performed in $20 \mu \mathrm{l}$ mix containing: $120 \mathrm{ng} / \mu \mathrm{l}$ DNA, $1 \times$ PCR buffer (Promega, 
USA), $2.5 \mathrm{mM} \mathrm{MgCl}_{2}, 0.2 \mathrm{mM}$ dNTPs (Fermentas, Lithuania), $0.5 \mathrm{mM}$ primers (provided by the Institute of Biochemistry and Biophysics, Pol. Acad. Sci.), 0.2 U GoTaq ${ }^{\mathrm{TM}}$ DNA Polymerase (Promega, USA). The following PCR thermal profiles were used for each set of primers: initial denaturation at $95^{\circ} \mathrm{C}$ for 4 min followed by 30 cycles of DNA denaturation at $95^{\circ} \mathrm{C}$ for $30 \mathrm{~s}$, primer annealing at $50-60^{\circ} \mathrm{C}$ for $45 \mathrm{~s}$ and DNA chain elongation at $72^{\circ} \mathrm{C}$ for $2.5 \mathrm{~min}$. The final elongation was conducted at $72^{\circ} \mathrm{C}$ for $5 \mathrm{~min}$. Electrophoretic separation of the PCR products was conducted on 3\% agarose gel (High Resolution, Sigma-Aldrich, St. Louis, USA) and visualized under UV using ethidium bromide. The size of the PCR products was assessed via comparison with a standard molecular weight marker (MassRuler ${ }^{\mathrm{TM}}$ DNA Ladder Mix - 80-10,000 bp, Fermentas, Lithuania).

Table 1. List of SSR primer sequences and their annealing temperatures (Ta)

\begin{tabular}{|l|c|c|l|}
\hline \multicolumn{1}{|c|}{ Primer } & Ta & Repeat motif & \multicolumn{1}{|c|}{ Primer sequence } \\
\hline Str60INRA & $60^{\circ} \mathrm{C}$ & GT & $\begin{array}{l}\text { 5'-CGGTGTGCTTGTCAGGTTTC-3' } \\
\text { 5'-GTCAAGTCAGCAAGCCTCAC-3' }\end{array}$ \\
\hline Str73INRA & $58^{\circ} \mathrm{C}$ & GT & $\begin{array}{l}\text { 5'-CCTGGAGATCCTCCAGCAGGA-3' } \\
\text { 5'-CTATTCTGCTTGTAACTAGACCTA-3' }\end{array}$ \\
\hline Str85INRA & $55^{\circ} \mathrm{C}$ & $\mathrm{CT}$ & $\begin{array}{l}\text { 5'-GGAAGGAAGGGAGAAAGGT-3' } \\
\text { 5'-GGAAAATCAATACTAACAA-3' }\end{array}$ \\
\hline Str591INRA & $55^{\circ} \mathrm{C}$ & $\mathrm{CT}$ & $\begin{array}{l}\text { 5'-CTGGTGGCAGGATTTGA-3' } \\
\text { 5'-CACTGTCTTTCGTTCTT-3' }\end{array}$ \\
\hline T3-13 & $54^{\circ} \mathrm{C}$ & GT & $\begin{array}{l}\text { 5'-CCAGTTAGGGTTCATTGTCC-3' } \\
\text { 5'-CGTTACACCTCTCAACAGATG-3' }\end{array}$ \\
\hline Strutta 12 & $56^{\circ} \mathrm{C}$ & GT & $\begin{array}{l}\text { 5'-AATCTCAAATCGATCAGAAG-3' } \\
\text { 5'-AGCTATTTCAGACATCACC-3' }\end{array}$ \\
\hline Ssa197 & $60^{\circ} \mathrm{C}$ & GTGA (+GT) & $\begin{array}{l}\text { 5'-GGGTTGAGTAGGGAGGCTTG-3' } \\
\text { 5'-TGGCAGGGATTTGACATAAC-3' }\end{array}$ \\
\hline Ssa85 & $60^{\circ} \mathrm{C}$ & GT & $\begin{array}{l}\text { 5'-AGGTGGGTCCTCCAAGCTAC-3' } \\
\text { 5'-ACCCGCTCCTCACTTAATC-3' }\end{array}$ \\
\hline OmyFgt1TUF & $60^{\circ} \mathrm{C}$ & GT & $\begin{array}{l}\text { 5'-AGATTTACCCAGCCAGGTAG-3' } \\
\text { 5'-CATAGTCTGAACAGGGACAG-3' }\end{array}$ \\
\hline
\end{tabular}

\section{Statistical analysis of the results}

The results were stored on a BioRad gel documentation system and analysed using the Quantity-One ${ }^{\circledR}$ software (BioRad, USA). The number of alleles per locus $(\mathrm{Na})$ and the number of effective alleles per locus $(\mathrm{Ne})$ were calculated for each investigated population and for all populations at the same time. Genetic information was determined for nine SSR loci in 2 populations using the following indices: number of private alleles per population (Np), Shannon diversity index (I) (Shannon, Weaver, 1949), observed heterozygosity $\left(\mathrm{H}_{\mathrm{O}}\right)$, expected heterozygosity $(\mathrm{He})$, unbiased expected heterozygosity $(\mathrm{uHe})$, inbreeding coefficient $\left(\mathrm{F}_{\mathrm{IS}}\right)$, fixation index $\left(\mathrm{F}_{\mathrm{ST}}\right)$. Variability per locus was measured using the coefficient of Polymorphic Information Content (PIC) (Anderson et al., 1993).

$$
P I C=1-\sum_{i}^{n} p_{i}^{2},
$$

where: $p-$ band frequency. 
The genetic similarity between populations was expressed using Nei's genetic distance (Nei et al., 1983). All calculations were done with GenStat 15th Edition and GenAlEx v. 6.5b4.

\section{Results}

The investigated populations were characterized by a high level of genetic variability (Tables 2 and 3). In all of them, the mean number of alleles per locus (Na) was higher than or equal to the mean number of effective alleles per locus (Ne) (Table 3). Shannon diversity index (I) was insignificantly lower in the lower Oder population compared with the other investigated population. The observed heterozygosity (Ho) was lower than the expected heterozygosity (He) in all populations and most heterozygotes were observed in the Oder river population, while the least were observed in the Pomeranian Bay population (Tables 2 and 3). Private alleles were observed exclusively in common whitefish inhabiting Pomeranian Bay (Table 3). Statistical analyses

Table 2. Genetic coefficients of variation of the investigated populations based on the 9 SSR primers

\begin{tabular}{|c|c|c|c|c|c|c|c|c|c|}
\hline Pop & 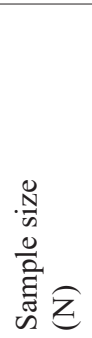 & 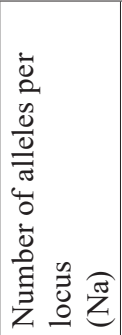 & 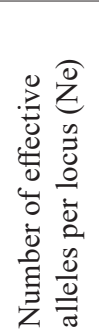 & 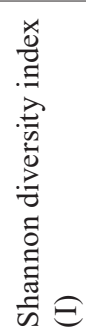 & 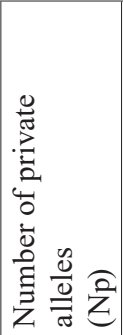 & $\begin{array}{l}\text { D } \\
0 \\
00 \\
0 \\
0 \\
0 \\
0 \\
0 \\
0 \\
0 \\
0 \\
0 \\
0 \\
0 \\
0 \\
0 \\
0 \\
0\end{array}$ & 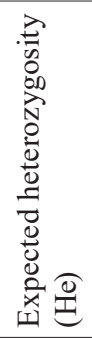 & 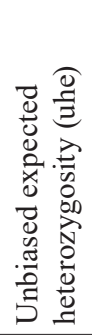 & 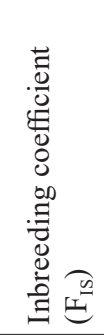 \\
\hline Pon & 26 & 1.889 & 1.630 & 0.463 & 0.540 & 0.450 & 0.308 & 0.316 & -0.412 \\
\hline Lower Oder & 19 & 1.667 & 1.661 & 0.460 & 0.00 & 0.652 & 0.332 & 0.398 & -0.922 \\
\hline
\end{tabular}

Table 3. Summary statistics of the results for microsatellite data

\begin{tabular}{|c|c|c|c|c|c|c|}
\hline Locus & $\begin{array}{l}\frac{0}{0} \\
\stackrel{0}{E} \\
\dot{z} \\
\dot{z}\end{array}$ & 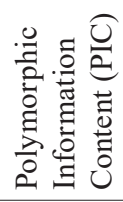 & 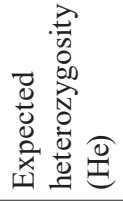 & 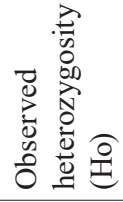 & 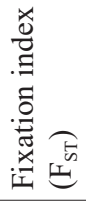 & 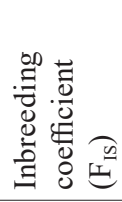 \\
\hline Ssa197 & 3 & 0.75 & 0.53 & 0.80 & 0.05 & -0.52 \\
\hline Str85INRA & 2 & 0.70 & 0.50 & 1.00 & 0.00 & -1.00 \\
\hline OmyFgt1TUF & 2 & 0.81 & 0.00 & 0.00 & 1.00 & - \\
\hline Str60INRA & 2 & 0.78 & 0.49 & 0.90 & 0.01 & -0.83 \\
\hline Str73INRA & 3 & 0.90 & 0.05 & 0.03 & 0.06 & 0.46 \\
\hline T3-13 & 1 & 0.85 & 0.00 & 0.00 & - & - \\
\hline Strutta12 & 2 & 0.58 & 0.49 & 0.94 & 0.01 & -0.91 \\
\hline Ssa85 & 3 & 0.47 & 0.38 & 0.75 & 0.43 & -1.00 \\
\hline Str591INRA & 2 & 0.82 & 0.50 & 1.00 & 0.00 & -1.00 \\
\hline Mean & 2.22 & 0.74 & & & 0.20 & -0.68 \\
\hline
\end{tabular}


Table 4. Genetic variability between the investigated populations $\left(\mathrm{F}_{\mathrm{ST}}\right)$

\begin{tabular}{|l|c|c|}
\cline { 2 - 3 } \multicolumn{1}{c|}{} & Pomeranian Bay & Lower Oder \\
\hline Pomeranian Bay & 0.000 & \\
\hline Lower Oder & 0.215 & 0.000 \\
\hline
\end{tabular}

revealed that the investigated whitefish populations are characterized by inbreeding coefficient $\left(\mathrm{F}_{\mathrm{IS}}\right)$ below zero, which indicates a high excess of heterozygotes (Tables 2 and 3). The coefficient of Polymorphic Information Content (PIC) values for each of the SSR (Simple Sequence Repeats) primers ranged from 0.47 to 0.90 . The mean value of this index was 0.74 (Table 3 ). The observed heterozygosity values generated by each SSR primer were between 0 and 1, while the values of expected heterozygosity ranged from 0 to 0.53 (Table 3 ). The level of genetic variability between the populations was determined using the $F_{S T}$ parameter. The genetic distance between the investigated whitefish populations is great $(0.215)$ (Table 4$)$. The percentage of polymorphic loci was identical in the two investigated populations $(66.67 \%)$.

\section{Discussion}

In the region of the Baltic Sea, the reduction of the common whitefish population is a result of intensive fishing and environmental pollution. The rapid loss of genetic diversity leads to decreased adaptation capabilities and an increased risk of extinction of the species (Frankel, Soul, 1981; Frankham, 1995). If restoration of an endangered species is performed, genetic monitoring should be conducted in parallel to avoid changes in the genetic structure and the impoverishment of the gene pool of the population (Fraser, 2008; Fopp-Bayat, Wiśniewska, 2010). The morphological and genetic variability of Coregonus maraena was assessed using microsatellite sequences (Bernatchez et al., 1999; Lu, Bernatchez, 1999; Østbye et al., 2004; Hansen et al., 2008) and mitochondrial DNA (Kohlmann et al., 2007; Kempter et al., 2010).

In this study, polymorphisms among common whitefish populations were determined using the microsatellite markers, successfully employed in the assessment of genetic variability and the degree of similarity between fish species (Fopp-Bayat, Wiśniewska, 2010; Säis et al., 2008; Winkler, Weiss, 2008; Dierking et al., 2014).

The values of expected heterozygosity (He), obtained by employing microsatellite sequences in the study of Coregonus maraena populations, ranged from 0.308 to 0.332 . The level of heterozygosity of the investigated populations of common whitefish is lower than in the Alpine populations from Austria $(\mathrm{He}=0.37-0.95)$ (Winkler, Weiss, 2008) and three naturally reproductively isolated whitefish taxa in Germany $(\mathrm{He}=0.66-0.76)$ (Dierking et al., 2014), but similar to that of Norwegian populations (Østbye et al., 2004). The high number of heterozygotes may be related with a more intense influx of genes from outside of the local population. Various studies indicate that many fish populations, such as Culter erythropterus (Wang et al., 2007), Engraulis encrasicolus (Zarraonaindia et al., 2009), or the investigated Coregonus lavaretus (McCairns et al., 2012), face the problem of a reduced frequency of heterozygotes due to inbreeding (O'Reilly et al., 1996). It is therefore a very positive signal that no such phenomenon is observed in the two investigated populations of common whitefish. Surprising is the fact that the presence of private alleles $(\mathrm{Np})$, occurring exclusively in a given population, was observed only in the common 
whitefish population of Pomeranian Bay. This means that the other populations are characterized by a lower genetic variability. It may be a result of the disappearance of those alleles due to genetic drift or due to the failure to fully detect the polymorphism of these populations. The high genetic variability of common whitefish inhabiting Pomeranian Bay, compared with the lower Oder population, is also demonstrated by the genetic variability coefficient $\left(\mathrm{F}_{\mathrm{ST}}=0.215\right)$. The population of Pomeranian Bay did not reveal such genetic homogeneity. Low $F_{S T}$ values are usually characteristic of the Coregonus populations, despite the morphological and ecological diversity of the genus. The $F_{S T}$ values of the common whitefish populations from 8 Alpine lakes, averaging at 0.049 (Douglas et al., 1999), or those of the populations from Norwegian lakes, ranging from 0 to 0.0143 (Østbye et al., 2004), are examples of this phenomenon.

The high level of genetic variability retained by the investigated common whitefish populations indicates that despite the significant reduction of the number of individuals, no effect of genetic drift has occurred. As a result of the long-term effect of the process, a reduction in the intra-population variability occurs along with an increase in the inter-population variability.

The conducted study demonstrated a high genetic variability between the analysed common whitefish populations, which may be explained by the mass introduction of the species into waterbodies without proper identification (Szczerbowski, 2000). It is even hypothesized that finding a pure form of common whitefish is very unlikely (Witkowski et al., 2009).

Continuous genetic monitoring is necessary in the process of renewal of endangered species in order to prevent the disruption of the genetic structure of the population (Fopp-Bayat, 2010). The need to know and to characterize this structure as many populations also indicate other researchers (Pamminger-Lahnsteiner et al., 2009).

Our results characterize the selected populations of whitefish and may be useful for further research on this species.

\section{Acknowledgments}

This study was partially financed by the European Union Sectoral Operational Programme Sustainable development of the fisheries sector and coastal fishing areas 2007-2013, no. 00001-61724-OR1600004/10.

\section{References}

Anderson, J.A., Churchill, G.A., Autrique, J.E., Tanksley, S.D., Sorrells, M.E. (1993). Optimising parental selection for genetic linkage maps. Genome, 36, 181-186.

Bernatchez, L., Chouinard, A., Guoqing, L. (1999). Integrating molecular genetics and ecology in studies of adaptive radiation: whitefish, Coregonus sp., as a case study. Biological Journal of the Linnean Society, 68, 173-194.

Dierking, J., Phelps, L., Præbel, K., Ramm, G., Prigge, E., Borcherding, J., Brunke, M., Eizaguirre, C. (2014). Anthropogenic hybridization between endangered migratory and commercially harvested stationary whitefish taxa (Coregonus spp.). Evolutionary Applications, 7 (9), 1068-1083.

Douglas, M.R., Brunner, P.C., Bernatchez, L. (1999). Do assemblages of Coregonus (Teleostei: Salmoniformes) in the central Alpine region of Europe represent species flocks? Molecular Ecology, 8, 589603. 
Estoup, A., Presa, P., Krieg, F., Vaiman, D., Guyomard, R. (1993). (CT) $)_{\mathrm{n}}$ and (GT) microsatellites: a new class of genetic markers for Salmo trutta L. (Brown trout). Heredity, 71, 488-496.

Fopp-Bayat, D., Wiśniewska, A. (2010). Analiza genetyczna siei (Coregonus lavaretus) z jeziora Łebsko zastosowanie analizy mikrosatelitarnego DNA. In: Z. Zakęś, K. Demska-Zakęś, A. Kowalska (eds.), Rozród, podchów, profilaktyka ryb rzadkich i chronionych oraz innych gatunków (pp. 65-72). Olsztyn: Wydawnictwo IRS.

Frankel, O.H., Soul, M. (1981). Conservation and Evolution. Cambridge University Press.

Frankham, R. (1995). Effective population size/ adult population size ratios in wildlife: a review. Genetics Research, 66, 95-107.

Fraser, D. 2008. How well can captive breeding programs conserve biodivesity? A review of salmonids. Evolutionary Applications, 2, 1-52.

Hansen, M.M., Fraser, D.J., Als, T.D., Mensberg, K.-L.D. (2008). Reproductive isolation, evolutionary distinctiveness and setting conservation priorities: The case of European lake whitefish and the endangered North Sea houting (Coregonus spp.). BMC Evolutionary Biology, 8, 137.

Heese, T., Lampart-Kałużnicka, M., Arciszewski, M., Modzelewski, T. (1999). Anadromous whitefish (Coregonus lavaretus $f$. lavaretus) from Łebsko Lake. Słupsk, Proc. XVII Meeting of PTZool.

Kempter, J., Kohlmann, K., Panicz, R., Sadowski, J., Keszka, S. (2010). Genetic variability in European populations of Coregonus lavaretus (L.): an assessment based on mitochondrial ND-1 gene haplotypes. Archives of Polish Fisheries, 18, 197-204.

Kohlmann, K., Kempter, J., Kersten, P., Sadowski, J. (2007). Haplotype variability at the mitochondrial ND-1 gene region of Coregonus lavaretus from polish lakes. Advances in Limnology, 60, 47-57.

Lu, G., Bernatchez, L. (1999). Correlated trophic specialization and genetic divergence in sympatric whitefish ecotypes (Coregonus sp.): support for the ecological speciation hypothesis. Evolution, 53, 157171.

Mccairns, R.J.S., Kuparinen, A., Panda, B., Jokikokko, E., Merila, J. (2012). Effective size and genetic composition of two exploited, migratory whitefish (Coregonus lavaretus lavaretus) populations. Conservation Genetics, 6 (13), 1409-1520.

Nei, M., Tajima, F., Tateno, Y. (1983). Accuracy of estimated phylogenetic trees from molecular data. Journal of Molecular Evolution, 19, 153-170.

O'reilly, P.T., Hamilton, L.C., Mcconnell, S.K., Wright, J.M. (1996). Rapid analysis of genetic variation in Atlantic salmon (Salmo salar) by PCR multiplexing of dinucleotide and tetranucleotide microsatellites. Canadian Journal of Fisheries and Aquatic Sciences, 53, 2292-2298.

Østbye, K., Amundsen, A., Bernatchez, A., Klemetsen, R., Knudsen, R., Kristoffersen, R., Næsje, F., Hindar, K. (2004). Parallel evolution of ecomorphological traits in the European whitefish Coregonus lavaretus (L.) species complex during postglacial times. Molecular Ecology, 15, 3983-4001.

Presa, P., Guyomard, R. (1996). Conservation of microsatellites in three species of salmonids. Journal of Fish Biology, 49, 1326-1329.

Säis, M., Rönn, J., Aho, T., Björklund, M., Pasanen, P., Koljonen, M.L. (2008). Genetic differentiation among European whitefish ecotypes based on microsatellite data. Hereditas, 2 (145), 69-83.

Shannon, C.E., Weaver, W. (1949). The Mathematical Theory of Communication. Urbana, University of Illinois Press.

Slettan, A. (1995). GenBank Acc. no. Z49134.

Slettan, A., Olsaker, I., Lie, ̌̌ . (1995). Atlantic salmon, Salmo salar, microsatellites at the SSOSL25, SSOSL85, SSOSL311, SSOSL417 loci. Animal Genetics, 26, 281-282. 
Szczerbowski, J.A. (2000). Whitefish (Coregonus lavaretus L.). In: M. Brylińska (ed.), Freshwater fish of Poland (pp. 381-386). Warszawa: Wydawnictwo Naukowe PWN.

Wang, C., Yu, X., Tong, J. (2007). Microsatellite diversity and population genetic structure of redfin culter (Culter erythropterus) in fragmented lakes of the Yangtze River. Hydrobiology, 1 (586), 321-329.

Wilkonska, H., Zuromska, H. (1982). Effect of environmental factors and egg quality on the mortality of spawn in Coregonus albula (L.) and Coregonus lavaretus (L.). Polskie Archivum Hydrobiologii, 1 (29), 123-157.

Winkler, K.A., Weiss, S. (2008). Eighteen new tetranucleotide microsatellite DNA markers for Coregonus lavaretus cloned from an alpine lake population. Molecular Ecology Resources, 5 (8), 1055-1058.

Wiśniewska, A.M., Pawelczyk, K., Sobocki, M. (2010). Systemy informacji przestrzennej - możliwość zastosowania w działaniach związanych z ochroną ichtiofauny. Biuletyn Naukowy UWM, 31, 5-10.

Witkowski, A., Kotusz, J., Przybylski, M. (2009). Stopie zagrożenia słodkowodnej ichtiofauny Polski: Czerwona lista minogów i ryb - stan 2009 The degree of threat to the freshwater ichthyofauna of Poland: Red list of fishes and lampreys-situation in 2009, Chronmy Przyrodę Ojczysta, 1 (65), 33-52.

Zarraonaindia, I., Pardo, M.A., Iriondo, M., Manzano, C., Estonba, A. (2009). Microsatellite variability in European anchovy (Engraulis encrasicolus) calls for further investigation of its genetic structure and biogeography. ICES Journal of Marine Science, 10 (66), 2176-2182.

Cite as: Achrem, M., Skuza, L., Kirczuk, L., Domagała, J., Pilecka-Rapacz, M., Czerniawski, R. (2017). Assessment of genetic variability in common whitefish from the catchment area of the Oder river using microsatellite markers. Acta Biologica, 24, 5-13. DOI: 10.18276/ab.2017.24-01. 